\title{
7 Minding the Gap: Mimetic Imperfection and the Historiographical Enterprise
}

\section{Historiography: looking at and through the text}

Historiography, ${ }^{1}$ 'the writing of history', must be one of the most ill-defined terms in our repertoire and its ambiguity lies productively at the heart of this volume. ${ }^{2}$ On the one hand, it refers to the activity of modern scholarship, the attempts of historians in the modern world to write about the past, using a variety of approaches and conceptual frameworks, viewing the evidence through different prisms, often reflecting contemporary preoccupations or historical contexts. On the other, it refers to the study by modern historians of attempts by historians in the ancient world to do the same. Historiography is conducted at various levels and degrees of remove, both a past reality in its own right and a representation of reality at the same time.

The duality inherent in the term is neatly articulated in the course outline for an undergraduate paper in the Modern History degree at the University of Oxford, ${ }^{3}$ which claims that 'Historians commonly approach the study of historical writing in two quite distinct ways: either by study of the techniques which we hold to be immediately relevant today, or by looking at the "history of history", as for example by focussing on classic texts in Western historical writing'. The paper's initial focus is on the latter, and it places centre-stage, 'the close reading of texts which really will bear close reading - reading being still the most fundamental of all historical "methods".' The essential meaning of historiography, 'the writing of history', covers a range of possibilities, but as practitioners of ancient historiography, we tend to mean the latter of the two interpretations above, that

1 The sub-heading refers to the work of Ankersmit (1994), much of whose work on the philosophy of history has focused on the layered nature of the historiographical enterprise and on the historical text as a lens through which to view the past as well as an object of study in its own right.

2 See Becker 1938, 20-8, for an early modern attempt to define the field as 'the study of the history of historical study' (20), which he sees as a piece of intellectual history in its own right. 3 Historiography: Tacitus to Weber. 
is reading works of history, pushing the act of writing into the hands of our ancient counterparts. ${ }^{4}$

Nevertheless, continuities in the writing of history across time are evident, and I shall argue for a close relationship between our own historical enterprise and that of our ancient predecessors, noting that the observations made by historians in the ancient world concerning the opportunities and constraints might reflect also on our own writing of history. I therefore propose to explore the core question of historiography, 'How do historians make history?', ${ }^{5}$ by reading what some historians in the ancient world have written about that process. As well as illuminating our reading of those historians as sources, by enhancing our understanding of their enterprise, this will also cast light on our own approaches to the writing of history.

Historiography is a self-reflexive enterprise, involving multiple layers of interpretation in which ancient practitioners, whose works we study, are engaged in a similar activity to that of their modern readers. It is an aspect of the ancient world which we study through its reduplication in the medium of its original production, making it unlike any other type of ancient evidence. ${ }^{6}$ Furthermore, the self-consciously analytical nature of ancient historiography aligns it closely with our modern enterprise. Ancient historiography does not simply reflect something of its contemporary society but is already a deliberate attempt to interpret events, situations, individuals, and to shape responses to them, and this tension between historical writing as a window through which to view the past as well as a feature of the past, an object of viewing in its own right, is one to which I shall return.

Since both ancient and modern historiography set out explicitly to offer an intellectually conceived and verbally expressed construction of the past, the notion of 'reconciliation' might appear superfluous. But the relationship between these enterprises is more complex than simple parallelism. The 'ancient' and 'modern' historiographies are distinguished by distance from the object of study, but they are also 'layered' enterprises, with modern historiography characterized as the study of ancient attempts to represent the past, turning ancient historiography into a piece of intellectual history in its own right. These coexistent but

\footnotetext{
4 The 'Historiography' paper based in Oxford's Classics Faculty also defines historiography as a reading exercise, focused on 'the history of history': 'Greek and Roman historical writers offer us a remarkable collection of narratives... This option focuses on particularly rewarding sections from some of the best-known historians.'

5 Faculty of History, University of Oxford, 'Disciplines of History' course description.

6 See Cameron 1989a, 4, for historiography as a 'text upon text', where the historian has to read and interpret materials before creating his own text.
} 
interwoven and enmeshed interpretations of what precisely constitutes the historiographical enterprise are mutually supportive. ${ }^{7}$ Thus the gap between ancient and modern historiography may be bridged in many ways.

\section{Bridging ancient and modern: parallel historiographical enterprises}

One apparent discontinuity, however, between ancient and modern historiography is the very purpose of writing history, declared by many ancient historians particularly in the Roman tradition to be primarily didactic and moralizing. Livy's 'lessons of every kind set out as on a conspicuous monument, from which you may choose which to imitate and which to avoid' (1 Preface 9-10) and Diodorus Siculus' proclamation that 'the understanding of the failures and successes of others, which is gained by the study of history, offers an education which is free from actual experience of ills' (1.1.1) both indicate that the historian's task is to teach. The validity of this claim was under critical scrutiny already in the Greek world, implied not least in Thucydides' pessimistic doubting of the capacity of any human truly to learn from the past. ${ }^{8}$ As Thucydides notes in relation to both the plague at Athens and stasis in Corcyra, ${ }^{9}$ the propensity for tragic events to repeat periodically meant that it was useful to record the symptoms so that a named diagnosis might be made more quickly in future, but there could be no expectation that such knowledge would avert the disaster next time. ${ }^{10}$ The same pertained to the pathology of the state. ${ }^{11}$ Nevertheless, in spite of Thucydides' reservations, didacticism was a strong thread in Roman historiography.

7 Cameron 1989a, 5: 'Thus history-writing is not a simple matter of sorting out 'primary' and 'secondary' sources; it is inextricably embedded in a mesh of text.'

8 See the classic scholarly treatment of the theme by Rutherford 1994. Pownall 2004 and Hau 2016 both offer illustrations of how the moralizing tendency in ancient historiography is played out.

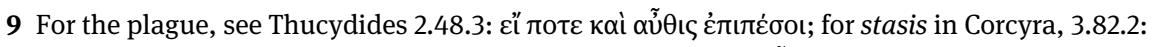

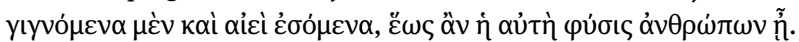

10 Thucydides 2.48.3: 'But I shall describe how it progressed, and the symptoms by which anyone who knows them beforehand may recognize the illness, if it should ever strike again.'

11 See Thucydides' account of civil strife or stasis at 3.82.2: 'Many difficult things struck the cities on account of civil strife, such as happen and always will happen as long as human nature remains the same.' 
This moralizing mission seems hard to relate to modern historiography, not least because of the changed role of the historian in society. The modern disjunction between historiography and statecraft, so tightly linked in the ancient world, entails a change in readership away from those who might need instruction in practical politics through study of the past. The ancient readership comprising the educated élite, including the ruling class of statesmen, is replaced most obviously in the modern world by two distinct groupings - an educated élite, comprising academics rather than statesmen, and a broader audience for so-called 'popular' history, as presented in accessible books, websites, and television programmes. Neither group is inclined to be 'taught' moral lessons by the historian.

However, various challenges can be made to this contrasting model. The involvement of contemporary historians in the development and formulation of public policy suggests that the notion of historical study as influential on the conduct of political life might still persist, although not through lessons learnt from the distant past as recommended by Livy and Diodorus. If there remains some continuity of influence on policy makers, then there are continuities too associated with another modern audience for historiography, the general public, in the form not of moral and political instruction, but of entertainment. As Pliny (Epistles 5.8) optimistically notes when contemplating the genre: 'history cannot fail to give pleasure whatever style is adopted' [sc. by contrast with poetry and oratory]. It is perhaps significant that Pliny, in the same letter, also discusses the potential of historiography as a means of winning fame and immortality for the historian. ${ }^{12}$ Here, the celebrity of some of the modern historians who bring the past to a wider audience through a range of entertainment media springs to mind, ${ }^{13}$ suggesting a point of comparison between ancient and modern historiography as produced for its entertainment-value by those who seek renown.

Indeed, while the grand narratives of ancient historians such as Thucydides and Tacitus may have been aimed at a relatively restricted and highly educated readership of the ruling élite, it is worth remembering that not all ancient historiography fitted this mould. The fragmentary remains of the vast numbers of local historians who flourished particularly in the Hellenistic period, suggest another major function for historiographical versions of the past, namely to instil and foster civic pride in the glorious history of a place, with the story often taken right

12 Pliny, Epistles 5.8.1: 'It seems to me a particularly fine thing not to let fall into oblivion those who deserve immortality, and to spread the fame of others together with one's own' (aliorumque famam cum sua extendere).

13 Mary Beard, David Starkey, and Michael Wood are all figures in the UK with a major public persona linked to their presentation of the Ancient World. 
back to the heroic period. The civic context for live performances of these historical works forces us to modify the picture of ancient historiography being produced solely or predominantly for an élite and restricted readership, as well as giving an insight into the extraordinary fame and honours attached to polished practitioners. ${ }^{14}$

Although the didactic purpose of ancient historiography seems misplaced in a modern context, nevertheless the related commemorative function of historiography forms a continuous bridge from the ancient to the modern worlds. Herodotus' declared intent to put on display his enquiry so that 'so that things done by man might not be obliterated by time, nor great and wonderful deeds, some displayed by the Hellenes, some by the non-Greeks, fall into oblivion', ${ }^{15}$ set the model for recollection of the past being central to historiography, and not necessarily for moralising reasons. There is, however, an implicit connection between commemorating the past and avoiding the repetition of its failures, and this is true of the modern world too, perhaps most notably in the context of warfare. As seen above, rather counter-intuitively, this continuity between ancient and modern thinking links not the rarefied world of ancient readership with the rarefied world of modern academia, but rather the former with the broader audience of popular history. It is the general public to whom the message of, for example, Remembrance Day, is directed, and they who are urged not to forget past horrors; not the readers of scholarly tomes. Again, perhaps we see here reflected differences in the political and cultural context in which ancient and modern historiography take place, with the lessons of history being now directed more clearly to the people at large than to the ruling oligarchy of statesmen.

The question of why people write history, in either the ancient or the modern worlds, yields a range of responses, some of which indicate continuity and some disjunction between these two worlds. The same is true concerning the issue of constraint over what the historian may write and in what terms. The restrictions on historians at least under the tight reins of the Roman Principate are explicitly set out by Tacitus. At the start of the Histories he notes a marked shift in historiographical freedom heralded by the Battle of Actium:

While they were relating the affairs of the Roman people, they wrote with equal eloquence and freedom. After the battle had been fought at Actium, and it was in the interests of peace that all power should be brought together in one man, those great intellects passed away.

14 See Clarke 2008, 304-69, and most recently Thomas 2019, for extensive discussion of polishistories.

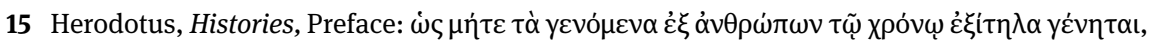

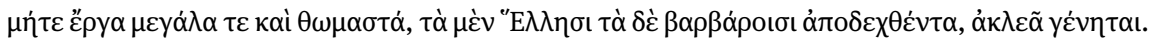


At the same time, truth was compromised in many ways; at first, through men's ignorance of public affairs, as though these were no longer their business, and soon through their passion for flattery, or, on the other hand, their hatred of domination. ${ }^{16}$

More resonantly, Tacitus' reference to book-burnings in the forum under the reign of Domitian (Agricola 2), as censorship hits both authors and their output, brings home the precarious place of the historian and his books under oppressive regimes: 'savagery raged against not only the authors themselves, but also their books' (neque in ipsos modo auctores, sed in libros quoque eorum saevitum). The crime in this case is to not to have written history, but to have written it 'wrongly', by praising opponents of the Principate. Thus not only dissidence but also the commemoration of dissidence is liable to penalty, and the writing of history becomes an act of opposition in its own right. More dramatically still, Tacitus' foregrounds at Ann. 4.34-5 the figure of the censured historian, Cremutius Cordus, put on trial for treason for writing the wrong kind of history, telling the wrong kinds of lessons, making the wrong people into heroes for emulation. ${ }^{17}$

By contrast, most modern academics would count themselves safely distanced from book-burning and other form of severe censorship, confident of joining Tacitus' Cremutius in the claim that no one cares what they write about the distant past: 'the ancient historian has few critics - nobody minds if he overpraises the Carthaginian (or Roman) army...' (Ann. 4.33). But this is to underplay the power of historiography and the investment made in particular versions of the past. One need look no further than controversy over treatments of episodes in twentieth-century history or colonial history across the centuries to realise that telling the 'right' version does matter and that not all versions are equally acceptable. Even if moral didacticism may seem less pressing within modern historiography than among the Roman historians, nevertheless any shaped historical narrative needs to persuade the reader that the 'correct' moral judgements attributing praise and blame have been drawn.

Fundamental questions concerning the scope of historiography - how far back should our study of the past delve, where does history start, and how should the span of time past be divided up - also clearly pertain to both the ancient and

16 Tacitus, Histories 1.1: Note the variation between this and the start of Tacitus' Annals, where he places the decline in historiographic freedom after rather than before the reign of Augustus. The lack of transparency in public affairs and the consequences for historiographical integrity are outlined also by Cassius Dio 53.19.

17 Tacitus, Annals 4.34: 'When Cornelius Cossus and Asinius Agrippa were consuls, Cremutius Cordus was tried on the novel charge, heard then for the first time, of publishing a work of history, in which he had praised Brutus and said that Cassius was the last of the Romans.' 
the modern worlds. Again, the ancient historians provide a cue, with Tacitus turning the question of where to start from a brain-teaser into an opportunity for political comment. Famously, the opening of the Annals makes mileage out of the suggestion that Roman imperial history actually began in the regal period, by opening the account of the period 'after the death of Augustus' ( $a b$ excesso divi Augusti) with the observation that 'from the beginning, Rome was ruled by kings' (urbem Romam a principio reges habuere). ${ }^{18}$

In many cases, setting the limits could be seen as more a problem than an opportunity. The periodization of Ancient History in universities and schools offers some clues as to the complexity of this question for modern syllabus-setters, ${ }^{19}$ and the academic debate about the interface between archaeology and history is, indeed, not so far removed from the musings of ancient historians over when their study should begin. For all, the issue is primarily one of evidence. Thucydides (1.21) criticizes the evidence provided by poets and logographoi, whose prime purpose was to please the audience and whose subject-matter was mostly swamped by tò $\mu \nu \theta \tilde{\omega} \delta \varepsilon \varsigma$ owing to the passage of time, a criticism which fits uncomfortably with Thucydides' own archaeology and early history of Sicily. Only two or three generations were seen as representing the limit of historical memory, ${ }^{20}$ in order to fulfil the criteria of accuracy and knowledge.

Outside the works of 'great historians', however, there was considerable enthusiasm for the realm of myth. The extant fragments of local Greek historiography positively embrace the opportunity to span the mythical, heroic age and the present day, allowing the latter to benefit from the kudos of the former. ${ }^{21}$ Universal historians too remained, in practice, unconstrained by the self-imposed discipline of Thucydides. According to Diodorus Siculus (4.1.2), Ephorus avoided the ancient mythological period because of its difficulty ( $\delta v \sigma \chi \varepsilon \dot{\rho} \rho \varepsilon \_$), presumably due to lack of evidence, ${ }^{22}$ but he still took his narrative back to the return of the Heracleidae (4.1.3). ${ }^{23}$ Ancient authors insisted that Ephorus was carefully vetting

18 Tacitus, Annals 1.1.1. This in spite of the oft-repeated protestation under that Principate that the principes were not reges; cf. Dio 52.40 and 53.17. See Clarke 2002.

19 Exempli gratia, in Oxford, Greek History used to start in $776 \mathrm{BC}$, the supposed date of the first Olympic Games; it was then moved 650 BC, leaving the world of early Mediterranean history to 'Greek Archaeology'.

20 See, for example, Finley 1975, 27.

21 On this, see Clarke 2008, 195-203.

22 See FGrH 70 F9, for this point implied. On Ephorus, see Clarke 2008, 96-8.

23 Note that Diodorus continues with the point that Kallisthenes and Theopompos likewise 'steered clear of ancient myths' ( $\dot{\alpha} \pi \varepsilon \dot{\sigma} \sigma \eta \sigma \alpha v \tau \tilde{\omega} v \pi \alpha \lambda \alpha i \tilde{\omega} v \mu v \dot{\theta} \omega v)$ ). See Parmeggiani 1999. Marincola 1997, 117-27, offers an excellent discussion of Diodorus 4.1.1-4 on myth in history. 
the strength of reliable sources, ${ }^{24}$ but the return of the Heracleidai still seems rather remote. Strabo's praise of Ephorus (Geography 10.3-4) for his early history of the Aetolians, for example, culminates in the judgement that he 'gave the best account of the foundation of cities, kinships, migrations, and original founders' (10.3.5), which makes attractive Schepens' suggestion that Ephorus was a key player in bridging the gap between the 'pre-history' concerning Panhellenic myths and sagas and the recent history of the Persian and Peloponnesian wars. ${ }^{25}$ This sense of bridging allows us to reconcile Ephorus' care for sources and disdain for the most remote past, with his evident inclusion of a past which far predated that of Herodotus. Diodorus himself regularly blurs the boundary between spatium mythicum and spatium historicum. ${ }^{26}$ The parameters of the chronological scope of historiography were clearly a subject for dispute in both the ancient and the modern worlds. ${ }^{27}$

Concern over evidence might seem to be belied by the lack of explicit scholarly apparatus in ancient historical works, which distinguishes ancient from modern attempts to write history. ${ }^{28}$ However, the earliest known exponents of the historiographical tradition, such as Herodotus and Hecataeus, illustrate the importance of having strong grounds for the facts and the narratives propounded. Herodotus uses not only autopsy (or professed autopsy), but also oral accounts and some written sources, leading to the notion that his work of history is literally a setting out of the evidence and a display of how to use it in a way which was superior to that of contemporaries and near predecessors, such as Hecataeus. ${ }^{29}$ Setting out evidence, weighing it up, acknowledging variant accounts, thinking about value of material evidence - all are methods with which any modern historian would recognize. ${ }^{30}$ Furthermore, the methods for using documentary evidence such as inscriptions could become a matter of historiographical controversy in their own right, as when Polybius criticizes Timaeus' false citation of the

24 See Schepens 1977, 96, for Ephorus' famed akribeia or 'accuracy'.

25 Schepens 1977, 97.

26 See Clarke 1999b, 255-6.

27 See Clarke 2008, 98-106, on the blurring of spatium mythicum and spatium historicum.

28 See, however, Lenfant who has explored extensively the phenomenon of citation by ancient historians. See, for example, Lenfant 1999, 2005, 2013.

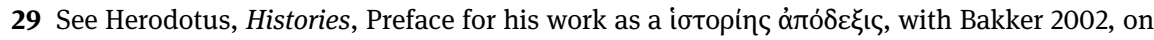
the meaning of this phrase.

30 Note how many Herodotean stories hinge on an object, such as 1.66.4 chains at Tegea; 5.77.2 shackles on the Acropolis. See Harris 2018, Dewald 1993, Bassi 2014. See Tacitus Annals 3.16, 3.19, 4.53 for different types of documentary evidence. 
epigraphy concerning the foundation of Locri (12.9-10). ${ }^{31}$ Competitive interaction with other historians also underpinned Dionysius of Halicarnassus' preoccupation with sources, noting that those who have already read Hieronymous, Timaeus, Polybius and others and see material in his work that is not in theirs might accuse him of invention and 'will demand to know how I came to know those details' (1.7.1). The need to prove his evidential credentials prompts Dionysius to tell the reader what narratives and records he has used (logoi and hypomnematismata). Furthermore, he claims to have spent twenty-two years in Rome, learning Latin and gathering information both orally and from a long list of Roman annalists. ${ }^{32}$

All of this suggests that the use of sources was more critical, knowing, and wide-ranging among ancient historians than is sometimes assumed. ${ }^{33}$ They were using a combination of primary, documentary, material, epigraphic evidence and the accounts of earlier and other contemporary historians - secondary sources, which put them at two removes from what they were writing about. Here we find a self-consciousness about not only directly handling the past these ancient historians were describing, but also being part of a literary continuum with which they need to be critically engaged. ${ }^{34}$ In this way some ancient historians strongly foreshadow our own two-fold attempts to write ancient history - a history of the past and a history of historiography itself.

31 On this fascinating passage, see Langslow 2013, 167-9.

32 See also Diodorus Siculus 1.4.2-5 for the claim to have learned Latin and used all the hypomnemata.

33 See, however, West 1985, for a systematic analysis of Herodotus' citation of both Greek and Oriental inscriptions in his work, in which she detects an occasionally casual approach to epigraphy, which is nevertheless explicable in terms of the predominantly oral culture in which he was operating and in which 'such inanimate, and indeed at times deceptive, testimony' as inscriptions might seem of peripheral value compared to that of oral logoi (305).

34 For the notion of continuators and a succession of historiography to stand alongside the continuum of history, see Clarke 1999b, 259-60. See Marincola 1997, 12, for the creative imitation of one's predecessors and the representation of reality as two forms of mimesis; also Gray 1987, 467. Schepens 1975, argues that the third-century Duris of Samos' mimetic programme focuses on 'imitation' of reality itself, not of previous artists or writers, thereby acknowledging the latter as a possible interpretation. 


\section{Bridging reality and representation: translating reality into text}

The self-consciously dual nature of both ancient and modern historiographical enterprises, concerned with both past realities and with literary attempts at their representation, serves to reinforce the ongoing continuum of historiography. Alongside the methodological similarities of purpose, freedom, scope and evidence, all of which bridge the gap between ancient and modern works of historiography, the duality of historiography as both a feature of the world, a reality worthy of its own study, and a representation of past reality, focuses attention of another form of bridging which lies at the heart of all historiographical enterprises - precisely that between reality and artistic representation. In a much-cited work, Frank Ankersmit argued that the historical text is 'no longer a layer through which one looks (either at a past reality or at the historian's authorial intention), but something which the historiographer must look at'. ${ }^{35}$ This seems to capture perfectly both what connects ancient and modern historiography, with the latter both looking at and looking through the former, and what characterizes all historiography as a reflection of reality that is of interest in its own right. ${ }^{36}$

The perplexing relationship between reality and its representation, like so many other methodological issues in historiography, is articulated explicitly by ancient authors. The fact that historical works are representative and constructed brings the problem of organization into sharp focus. ${ }^{37}$ Polybius notes when embarking on a monumental piece of historiography, one needs to know the beginning, middle and end before it is possible to start writing history (5.32.3-4), articulating a challenge which faces every historian trying to marshal his or her work and ideas into shape. The idea is echoed by Diodorus Siculus, with the comment that 'it should be the special care of historians to give attention to everything that may be of utility, and especially to the arrangement (oikovo $\mu$ i $\alpha$ ) of the varied material they present' (5.1). The challenge of translating a multi-dimensional reality into a literary text is articulated by Diodorus more fully later in his work:

35 Ankersmit 1994, 128.

36 See Bassi 2014, 174, for acute comments on 'the connection between the historical past and the historical text in the philosophy of history' and an effective use of Ankersmit's 'use of visual metaphors to refer to the epistemological dilemma that lies at the heart of historical narrative since the linguistic turn, namely, the relationship between the reality of the past and the rhetorical structures that shape that reality.'

37 See Moles 1993, 94, for the idea that 'Herodotus is not just commemorating history: he is creating it'. 
One might criticize historical narrative when one sees that in life many different actions happen at same time, but that those who record them must interrupt the narrative and distribute different times to simultaneous events, in an unnatural way. The result is that the actual experience of the events contains the truth, but the written record, deprived of such

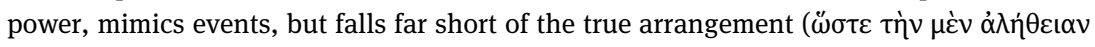

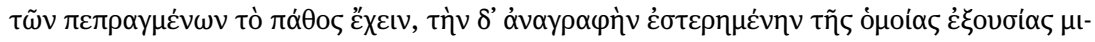

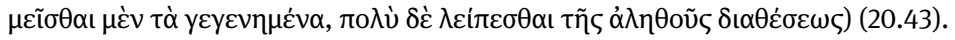

The identification of historiography as a form of mimesis offers many productive and interesting ways to think about the relationship between reality and representation, but let us first scrutinize the organizational challenges.

The axes of time and space within historical narratives form the matrix within which the reality of the world is imperfectly mapped into a literary form. It is clear that all literary attempts to represent reality need to find some way to convey in linear form the simultaneously spatial and temporal location, direction, and progression of the world under discussion, and that the relative dominance given to the different elements of time and space is an authorial choice. ${ }^{38}$ Whether time prevails as the overriding organizing principle, with spatial breadth figuratively spinning off to the sides; whether the driving force is a spatial one, with temporal depth drilling down intermittently, as in Strabo's work; ${ }^{39}$ whether the two planes of time and space are more evenly handled, resulting in a 'woven' narrative, such as those offered by Polybius and Diodorus himself ${ }^{40}$ - it is no surprise that it is the context of such methodological wrangling over how to represent what is effectively a 3-D reality in the 2-D world of the text that Diodorus makes his comments on the mimetic nature of historiography and the inability of the text perfectly to capture reality.

Historians in the ancient world make considerable mileage out of this organizational challenge, playing with the temporal and spatial frameworks which cause such narratalogical difficulties in order to draw out interpretative value. Take, for example, the opening of Tacitus' Annals. ${ }^{41}$ Here the temporal dimension is inevitably at the fore; the annalistic form which traditionally characterizes Roman historiography raises the expectation that the regular ticking of the magisterial clock will articulate the following narrative, with the only challenge being the one identified by Diodorus, namely that the multiple venues for action will

38 See Clarke 1999b.

39 Clarke 1999a, 245-93.

40 On woven narratives, see Clarke 1999b, 274-5.

41 Tacitus, Annals 1.1.1: urbem Romam a principio reges habuere. See Clarke 2002 for discussion of this opening. 
require the author to mesh together a narrative that has to suspend or even rewind temporal progression in order to encompass multi-locational action. The opening sentence, however, casts doubt on the likelihood that Tacitus' Annals will be this kind of conventional annalistic narrative. By starting with the words urbem Romam, Tacitus opens up the possibility that the spatial breadth of his work will be the global stage which Polybius (and Diodorus) had found difficult to tame into a linear narrative. Polybius had made the claim that Rome's empire resulted in a global history that moved as one with no multiple venues to worry about once the symploke had taken place and history had become 'corporate' or 'like a single body' (somatoeide), but later writers like Diodorus suggested otherwise. In the hands of Livy, the urbs and the orbis terrarum would again blend into an organic whole, one which was overburdened by its own magnitude (Livy 1 Preface 4: iam magnitudine laboret sua), but it is by no means clear whether this will be the case for Tacitus. Indeed, his own comments later in the work (4.32) indicate that the days of global excitement and the associated grand narrative died with the Republic. But in the opening two words of the Annals it remains an open question as to whether the work is going to be about the urbs Roma in its confined or its extended form.

Furthermore, the idea that the ticking of the magisterial clock will be the metronome which anchors the literary representation to the reality of Roman political life is called into question within this first sentence. urbem Romam a principio reges habuere - 'the city of Rome was, from the beginning, ruled by kings'. The regular cycle of Republican magistracies may not, after all, provide the heartbeat for Rome's history, but rather the longer and unpredictable articulation by reigns, whether they be of kings, dominant figures of the Republic, or emperors. Thus Tacitus plays with the reader's likely expectations about how the narrative of Roman history may be paced and spaced; about how he will deal with the difficulties of representation. His political comment is enmeshed within this historiographical question. ${ }^{42}$ Doubts about the political reality have ramifications for the historiographical representation precisely because historiography makes claims to truth and accuracy which set it apart from fiction, as will be explored below. But, because the act of mimesis is imperfect, the process always poses a challenge and offers a fertile ground for analysis.

42 See Ginsburg 1981, for the argument that Tacitus deliberately makes the Republican annalistic structure, with its chronological sequence and consular punctuation marks, cosmetically central but historically insignificant to his account. 
A spatial parallel is offered by Strabo's Geography, where the primary organizing principle is unsurprisingly that of space, but where a different mimetic dilemma is in play - how to represent within the spatially organized text change over time, both on the global scale and within communities. Strabo rises to this challenge with a range of tactics, drilling down from the real, conceptual and literary plane of the 'map' into the chronological dimension to offer potted histories of individual places and thereby making his text 3-D in terms of the time-space matrix; and simultaneously but implicitly building up broad geographical layers which offer a synchronic survey of 'how the world is' at particular key phases of the past - the Homeric world, the age of colonization, the growth of Rome's empire, the current peaceful glorious Augustan age. For an author who wins little acclaim, it is a complex, multi-layered and sophisticated piece of literary representation. ${ }^{43}$

Some ancient authors explicitly draw attention to the need for historiography to find ways of mapping narrative time and space to the ever-shifting configurations of political or 'real' time and space, while others illustrate it implicitly by their own literary choices. The mimetic gap acts as a locus for creativity at all levels, in terms of both authorial choice and later interpretation, illustrating the duality of historiography as a writing and reading activity.

\section{The mimetic mirror: exploiting the gap}

Diodorus' comment that historiography is not and cannot be the same thing as history itself, but entails a gap between reality and representation, bridged by some mimetic process, requires further discussion. ${ }^{44}$ The inherently representational nature of historiography, reinforced by Hayden White's work on formal-

43 See Clarke 1999a, especially 245-93.

44 See Gray 1987, 481-2, for the view that Diodorus here stresses second-hand versus true reality, rather than using mimesis as a technical term of literary criticism. However, the latter concept of mimesis was clearly also relevant to historiographical writings. At 469, she notes that for writers such as Dionysius of Halicarnassus, 'the meaning of mimesis in history is the recreation of reality, encompassing recreation of both character and emotion.' Aristotle's Poetics are clearly a key text. See 1447 a on poetry and other artistic forms as a 'representation of life' ( $\pi \tilde{\alpha} \sigma \alpha \iota$ tvyxó-

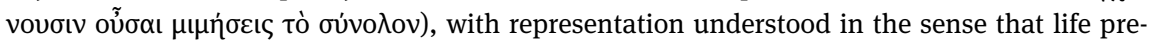
sents to the artist the phenomena of sense, which the artist re-presents in a variety of media, imposing a coherence and pattern in the process. 
ism, might appear to disengage the literary representation entirely from the reality it mimics. ${ }^{45}$ As Momigliano importantly noted, however, historiography is characterized by claims to truth which set it apart from fictive literary forms, and this has been reiterated by countless scholars of ancient historiography. ${ }^{46}$ The concern for truth and accuracy, repeated throughout the history of Classical historiography, whether it be manifested in Thucydidean aletheia or Tacitean concern over the effects on truthful discourse brought by the exigencies of the Principate, implies a relationship between reality and representation which is close and meaningful. Historiography claims to offer a truthful representation of its subject. It is not fiction, ${ }^{47}$ but rather it claims to be mimetic of reality. But Diodorus reminds us that, in addition to the gap between ancient and modern attempts to write history, there is also a gap that lies at the heart of any historiographical enterprise - the crucial, definitive, and tantalizing disjunction between reality and representation; the failure of the narrative to be the reality, however much some ancient historians may attempt to blur the distinction. ${ }^{48}$

For Diodorus the catalyst for these observations is the particular problem of how one can represent in a linear account events which happen simultaneously just one of the difficulties facing the historian, the creator of the representation. Diodorus is surely right that historiography can only mimic the events it represents, and that it can never replicate reality, although constituting a new reality as a piece of intellectual history in its own right. For Diodorus, this is a 'falling

45 See White 1973. See Ankersmit 1994, 194, for a strong expression of this concern: 'we may wonder whether the postmodernist theory of historical writing (...) still leaves room for the authenticity of historical experience. That is, for an authentic experience of the past in which the past can still assert its independence from historical writing.'

46 Momigliano 1981. Note Cicero De Oratore 2.35-6 on history as 'the illumination of true reality' (lux veritatis). See Rood 1998, 10, for the view that 'What distinguishes historical texts from fiction is the reader's assumption that they relate 'what actually happened' and discussing 'history as a discourse of the real'; also Pitcher 2009, viii, for the idea that treating historical writings as works of literature sometimes 'stands accused of strategically ignoring the fact that works of history, unlike most works of art, place themselves in a very particular relation to what some of us still like to think of as reality'; Cameron 1989b, 33: 'Historical narrative is distinguished from fictional narrative by its presumed connection with real events, in fact with truth', while Wheeldon 1989 , 44, points out that the reception of historical works as 'truthful' is largely determined by generic expectation, which dictates that history concerns res gestae rather than res fictae or res fabulosae.

47 Except in so far as all narrative is constructed. See Greenwood 2006, 66: 'In this sense fiction is intrinsic to historical narrative qua narrative, as long as we are clear that in this context, fiction is used in its primary sense to mean 'the creation of form in language'.

48 See, for example, Livy's claim to have 'written the real events of the Roman people' (res populi Romani perscripserim) 1 Preface 1. 
short'; the 'written record' is 'deprived of the power' of the reality. In Gorgias' terms, logos has the power to depict reality in such a way that 'the soul endures

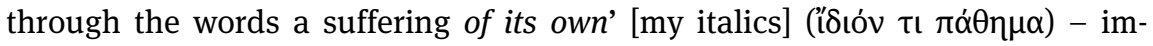
portantly close but not identical to the actual event. ${ }^{49}$

But this gap, the imperfect and compromised nature of historiography as a substitute for reality, offers an interpretative opportunity. As has been seen, there are many similarities in methodology between ancient and modern historiographies which allows us to consider them as parallel enterprises, but the observation made by Diodorus brings us back to the idea that the prime interpretation of 'historiography' for us entails 'reading ancient historians', historiography as an academic venture focused on the study of ancient historical texts, which explores and exploits the existence of the 'gap' between reality and representation, and considers various ways in which that gap is bridged, what mimetic devices are used so that the literary construct of the text meaningfully reflects the truth of the reality. This is the enterprise that historiographers are primarily engaged in: analysing the mimetic relationship between history and historiography; thinking about how historians bridge the gap, what devices they use to capture something of the 'essence', the 'truth', Thucydides' sympase gnome. ${ }^{50}$ The different prisms through which we read ancient historians thus facilitate a dialogue between clues fed to us by the text and our own interrogative frameworks.

Ancient authors use a variety of images to analyse this mimetic process, many of them strongly visual. ${ }^{51}$ Capturing a version of the truth is frequently articulated in terms of vividness, ${ }^{52}$ with this goal of enargeia foremost. Wiseman's work on the possible origins of Roman historiography in the world of the ludi Romani serves to highlight how naturally history may be thought of in dramatic

49 Gorgias 82 B11.9 DK, with Meier 2018, 303 n. 45.

50 See Thucydides 1.22 on his recording of speeches not verbatim, but: 'keeping as close as pos-

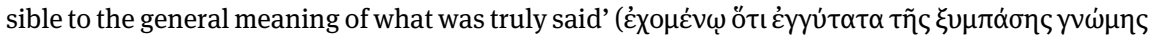
$\tau \tilde{\omega} v \dot{\alpha} \lambda \eta \theta \tilde{\omega} \varsigma \lambda \varepsilon \chi \theta \varepsilon \dot{v} \tau \omega v)$. See Greenwood 2006, 64. At 57-9, Greenwood interestingly discusses the idea of truth as the product of literary invention. Moles 1993, 106, observes the complexity of Thucydides' conception of truth at 1.22, noting that 'his speech material is a mixture of factual truth and imaginative truth, specific truth and general truth'.

51 See, for example, Plutarch Moralia 347a: 'the most effective historian is he who, by a vivid representation of emotions and characters, makes his narration like a painting'.

52 Walker 1993, 374, notes, 'As fiction, ancient historiography frequently sets as its goal verisimilitude - understood as a likeness to reality, and not as a fidelity to "the facts" - and its success was often measured, by ancient critics and historians alike, by the degree to which the representation is "visually perceived" by the reader.' 
terms, and indeed Greek historians also frequently write of history as a spectacle. ${ }^{53}$ But perhaps the most analysed account of the process by which historical reality is brought to the mind's eye of a reader is that by Lucian, How to Write History 51, in which the historian is exhorted to make his mind like a mirror which will reflect events as they really were. 'Above all, let him bring a mind like a mir-

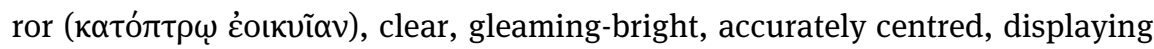
the shape of things just as he receives them, free from distortion, false colouring, and misrepresentation. ${ }^{54}$ It is, according to Lucian, not for the historian to invent the facts, which have already taken place, but to arrange them and put them into words. Like a work of sculpture, the historical text is fashioned and displayed 'as

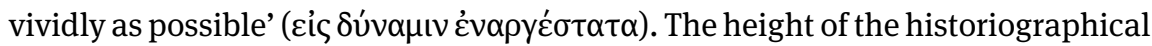
craft is achieved 'when a hearer subsequently thinks that he can see what is being

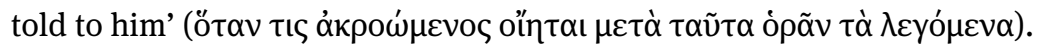

The image of the mirror perfectly encapsulates the tension between the idea that historiography must reflect a pre-existing reality, but that it will inevitably do so imperfectly and with some element of distortion. ${ }^{55}$ As Moles helpfully articulates, ${ }^{56}$ 'Both the historian ... and his readers ... are engaged in a process of 'looking' (skopein). Thus the historian's mimēsis of events, the product of his 'seeing' and 'looking', is like a mirror, at which he invites his readers to 'look'. But for the readers, as for the historian himself, the process of 'looking' is complex: to 'look' is not only to 'see' in a physical sense, but to 'contemplate', to 'attempt to understand', to 'reflect on'.' Moles' formulation issues a timely reminder of the multilayered process of viewing, interpretation, and writing that links our modern historiography with that of the historians whose works we study, both as windows through which to view past reality and as artefacts in their own right. The lens through which each writer 'reads' and 'writes' the reality which he represents, just as his decisions concerning the mapping of the world onto a linear text, are precisely what demand our attention as the focus of our modern reading of ancient texts. Historiography is a mimetic literary enterprise in which historical meaning is embedded in narrative structure and style, as well as in the configuration of time and space.

53 Wiseman 1994, 19. See Polybius 1.2.1; 1.64.3; 3.1.4; 9.9.10 for the spectacular nature of history. 54 On this passage, see the excellent discussion of Moles 1993, who observes (89) 'Surely mimesis through the medium of a mirror is as close to reality as one can get?'

55 See Moles 1993, 110, for the idea that what readers see in a historian's mirror 'is not a simple reflection of events but a reflection of specifics and general truths, and of the past, the present and the future'.

56 Moles 1993, 110. 


\section{Herodotus: master of mimesis}

These complexities are amply illustrated in the Histories of Herodotus. In terms of translating a complex reality of vast chronological and spatial scope into a single linear literary representation, it is hard to think of an ancient historian who faced a greater challenge. ${ }^{57}$ In addition, however, the text of Herodotus illustrates how historiography may be seen as a mimetic literary enterprise in which historical meaning is embedded in narrative structure and style. In an iconic scene in Book 4 of the Histories, where Herodotus has Darius march to where the Bosporus was bridged and sail to the so-called Wandering rocks to sit on a headland and view the Pontus, at the most basic level Herodotus offers himself a perfect opportunity to show off his extraordinary geographical knowledge:

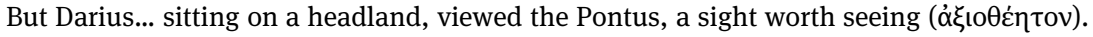
For it is the most wonderful of all the seas. Its length is 11,100 stades, and its breadth 3,300 stades at the point where it is widest. The channel at the entrance of this sea is 4 stades across; the narrow neck of the channel, called the Bosporus, across which the bridge was thrown, is about 120 stades long. The Bosporus reaches as far as the Propontis; and the Propontis is 500 stades wide and 1,400 long; its outlet is the Hellespont, which is 7 stades in width and 400 in length. The Hellespont empties into a gulf of the sea which is called the Aegean (485).

But the scene is far more complex than this. As is common in the Histories, Herodotus' elevated authorial viewpoint from which he looks down from afar on the vast stretches of land that make up the continents, separated by seas, straits, or major rivers, is here complemented by a further viewpoint which is focalized closer to the ground through a player in the narrative. The technique of inserting scenes within scenes and layers of spectating focuses the reader's attention on the process of viewing and representation. ${ }^{58}$

Darius' reaction to the sight that meets his eyes as he sits magisterially above the Black Sea provides the cue for the reader to share his wonder. ${ }^{59}$ The Pontic

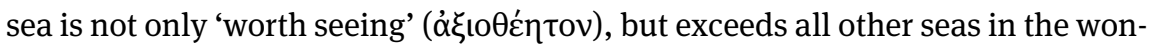
der it inspires. Herodotus' authorial viewpoint through which he allows us not only to share Darius' wonderment but also to join with him, Herodotus, in gazing

57 See Gould 1989, 42-62, for Herodotus' weaving together of micro- and macro-logoi. Clarke 2018, passim, addresses questions of spatial representation.

58 Walker 1993, 376.

59 See Grethlein 2015, 312, for the idea that 'narrative is not only a means of representation (as opposed to presence), but that it also has the capacity to trigger experiences in its recipients'. 
down upon the scene of that wonderment heightens the sense of marvel and reinforces the self-consciously constructed and representational nature of these layered views. As elsewhere, here Herodotus justifies his own sense of amazement through quantification, giving the dimensions in detail as he presents a miniature geography of the region, which brings home the interconnected sequence of seas, trickling down to the central Mediterranean. The shift in focalization from Darius to Herodotus hinges on the spectacle of the Pontus. In fact, it is left unclear whether the positive assessment of the Pontus belongs to Darius or Herodotus or both. ${ }^{60}$ Herodotus thereby offers a double-layering to the focalization, allowing the reader to view the world through Darius' eyes, but additionally sharing his own, more distant, perspective, in which Darius is a feature of the scene and the scope of his gaze is extended imaginatively by Herodotus from the point at which he is sitting right down to the outflow into the Aegean. ${ }^{61}$ In these two different but intertwined perspectives Herodotus the author marvels at nature and at man's productive relationship with it, but the Persians view the same world with desirous and destructive eyes. ${ }^{62}$ Herodotus' sense of geographical space is entangled with the more resonant and morally charged geographical vision of some of his characters. Here the creation of alternative focalisations or different representational frames opens up key interpretative questions over Herodotus' alignment with or opposition to or view of characters in the work. Of course, all perspectives fall within the all-encompassing scope of Herodotus as author of the work, but the consciously constructed nature of the narrative offers scope for the reader's viewpoints and responses to be shaped by the historian.

Furthermore, the literary device by which both the natural wonder of the connected seas and the human figure of Darius as their spectator are brought before the eyes of the reader is reinforced by the way in which the natural marvel is immediately followed in the narrative by the celebration of man's achievements. When Darius sails back to the bridge designed by Mandrocles of Samos, he indulges in yet more spectating - this time of the Bosporus itself. It is another natural feature viewed here, but the choice of viewing point is significantly no longer

60 See Christ 1994, for similar blurring in perspective between Herodotus and Darius at other key geographical features in the narrative - the river Tearus, the river Peneus.

61 Walker 1993, 373, notes that the figure of the historian as spectator of events illustrates the professed concern for autopsy. Herodotus' distanced perspective calls to mind Polybius' stress on the panoptic viewpoint of the historian, viewing the entirety of world history moving as though it were a single body.

62 See Clarke 2018, 65-6. 
the rocks but a bridge, and one which will span the continents. Here Darius celebrates another human marvel, namely the vast scale of his gathered army, which is inscribed on two pillars in Assyrian and Greek, a landscape of man's making. ${ }^{63}$

The triumph of man in creating everlasting wonders is emphasized by the reciprocal honours paid by Darius and Mandrocles (4.88). In return for Darius' thanks to Mandrocles, the latter has a picture made of the bridging of the Hellespont and of Darius sitting over it watching the army crossing. ${ }^{64}$ The wondrous efforts of nature and especially of man are brought together through the medium of artistic representation, commemorating the marvellous sight of Darius marvelling at not nature as we first saw him, but now the achievements of man in conquering the sea he had so admired. This painting adds yet another, third, layer to the focalization of Darius as viewer of the works of nature and of man, as now the viewpoint of the painter is inserted between that of Darius and that of the historian, and the telescopic reach of this narrative stretches out still further.

As Grethlein has noted, the insertion of an actual piece of artwork into the narrative at this point, focused on one of the players as internal viewer, highlights the iconicity of such 'viewing' scenes. ${ }^{65}$ Although, as Grethlein argues, various scenes of survey in the narrative, by freezing the moment of the narrative viewer's gaze, offer an experience to the reader similar to that of viewing a painting, ${ }^{66}$ the inclusion of actual works of art lifts the mimetic theme to new levels. Here, the painting which Herodotus had probably seen on Samos and from which he may have drawn inspiration for his description of other 'survey' scenes, such as the depiction of Xerxes with his troops at Abydos (7.44) or at Doriscus (7.60-1), ${ }^{67}$ interrupts and simultaneously enriches the line of viewing which would naturally have flowed from the reader through Herodotus then Darius and finally to the natural wonder of the Bosporus.

63 4.87. The pillars were afterwards carried by the Byzantines into their city and used to build the altar of Orthosian Artemis, except one column covered with Assyrian writing that was left beside the temple of Dionysus at Byzantium.

64 For a fuller discussion of this painting, see West 2013. West interestingly suggests that the iconography of the painting probably resembled that of survey scenes in Persian art, as on the Bisitun relief.

65 Although see Grethlein 2015, 320, for further nuance on the effect of telescopic viewings: 'When we concentrate on a picture in a picture or a film in a film, the awareness that what we see in the first place is only a picture or film fades without completely vanishing.'

66 Grethlein 2013, 194.

67 See Asheri, Lloyd, and Corcella (2007) ad 4.88, for Herodotus' use of the painting on Samos. 
In fact, Herodotus alludes directly to artistic evidence only rarely in his work. At 2.73, he refers to the phoenix, a bird which he has never seen, except in a pic-

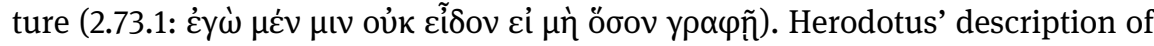
the bird is naturally dependent on the accuracy of this representation, a qualification which he makes explicit: 'It is of this size and appearance, if it really re-

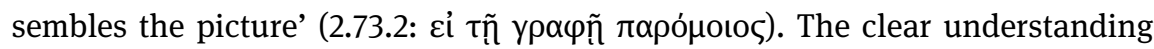
that the picture might not 'tell the truth' neatly expresses the imperfect mimesis of representative art, in a way which reminds the reader that this is a feature also of the historiographical account itself. ${ }^{68}$

Elsewhere, the imperfection of mimesis is illustrated through another artistic production, the map shown by Aristagoras to Cleomenes of Sparta when seeking his support for the Ionians against Persian aggression (5.49). The representational nature of the work of art is reinforced by the fact that it evokes a verbal commentary from Aristagoras, interpreting and articulating, this time in the medium of words rather than pictures, the geography of Asia. It is clear that neither the map nor the description can perfectly replicate the reality on the ground, the juxtaposition of two different versions being a stark reminder of this. Both words and images offer a mimesis, here designed to be mutually reinforcing. ${ }^{69}$ But the fact that the map and its description act as catalysts for Herodotus' own verbal account of the Persian Royal Road, mapped out in terms of distances, guard-stations, and rivers (5.52-3), brings the author into the self-conscious mimetic frame and adds the likelihood of dissonance. ${ }^{70}$ As it turns out, Herodotus' independent account of the geography of Asia acts as guarantor that Aristagoras was indeed broadly speaking the truth about when he claimed that the journey from the sea to Susa was three months, but Herodotus can go further in improving the precision of the distance, adding three days to the journey-length (5.54). ${ }^{71}$ The provisional and contestable nature of the representation is thus reinforced.

In this episode, the mimetic nature of the work of art not only produces a certain degree of inaccuracy in the leap between reality and representation, but this gap is creatively exploited by Aristagoras in order to manipulate Cleomenes' view of Asia, enhancing his vision of the lands he might rule. West notes the lack

68 See Tacitus, Annals 6.28, for a strikingly similar account of the phoenix and its habits.

69 Barker, Bouzarovski, and Pelling 2016, note that 'this episode invites us to consider what difference it makes to depict space using words rather than images' (5).

70 Branscome 2010; Branscome 2013, 105-49, discusses Aristagoras as a foil to Herodotus' superior knowledge.

71 See also Hornblower 2013, ad 5.54, for the ongoing competition for accurate knowledge of the route. Hornblower notes a third-century AD papyrus (P. Oxy. LXV 4455) querying Herodotus' results. 
of conventions concerning cartographic scaling in this period, ${ }^{72}$ which Aristagoras is almost successful in exploiting to lead Cleomenes to underestimate the distance from Sparta to Susa. ${ }^{73}$ Only when the savvy Spartan insists on knowing the distances being represented, does the deception fail. But in fact, Aristagoras at no point makes false claims about the size of Asia, simply leaving the truth unsaid. His deception concerns the benefits on offer, not the distances involved. At any rate, the constructed and mimetic nature of works of art within the text and of the text itself is reinforced.

Bringing these thoughts back to Mandrocles and his painting of Darius, if we are thinking about the gap between reality and representation in historiography, Herodotus' literary representation of an artistic representation of a scene in which the Persian king constructs a vision of the reality of which Herodotus himself is also a viewer, illustrates quite how engaged and interested ancient historians were in the whole process of creating narratives which bore a meaningful and 'truthful' relationship to reality while being self-consciously constructed and 'deprived of the power to convey the true experience of events', but nevertheless could 'mimic or imitate or represent' them. Mimetic imperfection perhaps, but one which offers a rich and fertile field of study for modern historiographers. As has been well observed, ${ }^{74}$ the phenomenon of mise en abyme or embedded tales, the representation of spectators in historical narrative, and the inclusion of visual artistic depictions all serve to indicate a high level of self-consciousness about the processes of reading, viewing and interpretation, as reality is somehow translated onto paper.

Herodotus' inclusion of a painting in this chain of views emphasizes the representational nature of all the layers, including that of his own text. The master of mimesis, the arch-film-director, zooming his lens in and out, drawing the reader's attention to the act of framing and the ways in which viewers, including some of his characters, may misrepresent reality, falls in turn within the reader's frame of analysis as an object of viewing, interpretation, framing, representation

72 For the notion of cartographic space as elastic, see Aristophanes, Clouds 215-16, where Strepsiades proposes increasing the distance between Sparta and Athens on the map:

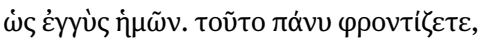

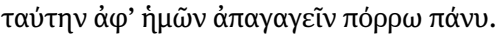

'How close it is to us. Take great care to move it far away from us.'

As Dover 1970, ad loc. notes, 'Strepsiades thinks of a map as a magical means of bringing places nearer together or further apart'.

73 West 2012, 165.

74 See, for example, Grethlein 2013, 2015; Walker 1993. 
in his own right and the subject of modern historiography. The coalescence between reader and spectator extends to all levels of the mimetic process. But, interesting though the viewers and viewed, the history and the historical text are, it is the gaps between them which offer depth of meaning and resonance in historical interpretation.

\section{Bibliography}

Ankersmit, Frank (1994), History and Tropology. The Rise and Fall of a Metaphor, Berkeley. Asheri, David/Lloyd, Alan/Corcella, Aldo (2007), A Commentary on Herodotus Books 1-1V, Oxford.

Bakker, Egbert J. (2002), “The Making of History: Herodotus' Histories Apodexis”, in Egbert J. Bakker/Irene J.F. de Jong/Hans van Wees, Brill's Companion to Herodotus, Leiden, 3-32.

Barker, Elton/ Stefan Bouzarovski/Christopher Pelling (2016), "Introduction: Creating New Worlds out of Old Texts", in Elton Barker/Christopher Pelling/Stefan Bouzarovski/Leif Isaksen (eds.), New Worlds from Old Texts. Revisiting Ancient Space and Place Oxford, 121.

Bassi, Karen (2014), “Croesus' Offerings and the Value of the Past in Herodotus' Histories”, in Christoph Pieper/James Ker (eds.), Valuing the Past in the Greco-Roman World: Proceedings from the Penn-Leiden Colloquia on Ancient Values VII. Mnemosyne Supplement 369, Leiden, 173-96.

Becker, Carl (1938), “What is Historiography?”, American Historical Review 44, $20-8$.

Branscome, David (2010), “Herodotus and the Map of Aristagoras”, Classical Antiquity 29, 144.

Branscome, David (2013), Textual Rivals. Self-Presentation in Herodotus' Histories, Ann Arbor, $\mathrm{MI}$.

Cameron, Averil (1989a), “Introduction: the writing of history”, in Averil Cameron (ed.), History as Text. The Writing of Ancient History, London, 1-10.

Cameron, Averil (1989b), “Introduction to M.J. Wheeldon, “True Stories”: the reception of historiography in antiquity", in Averil Cameron (ed.), History as Text. The Writing of Ancient History, London.

Christ, Matthew R. (1994) “Herodotean Kings and Historical Enquiry”, Classical Antiquity 13, 167-202.

Clarke, Katherine (1999a), Between Geography and History. Hellenistic Constructions of the Roman World, Oxford.

Clarke, Katherine (1999b), “Universal perspectives in historiography”, in Christina Kraus (ed.), The Limits of Historiography: Genre and Narrative in Ancient Historical Texts, Leiden, 24980.

Clarke, Katherine (2002) “In arto et inglorius labor: Tacitus' anti-history”, in Alan K. Bowman/ Hannah Cotton/Martin Goodman/Simon R.F. Price (eds.), Representations of Empire. Rome and the Mediterranean World, Oxford, 83-103.

Clarke, Katherine (2008), Making Time for the Past: Local History and the Polis, Oxford. 
Clarke, Katherine (2018), Shaping the Geography of Empire: Man and Nature in Herodotus' Histories, Oxford.

Dewald, Carolyn (1993), “Reading the World: The Interpretation of Objects in Herodotus' Histories”, in Ralph M. Rosen/Joseph Farrell (eds.), Nomodeiktes: Greek Studies in Honor of Martin Ostwald, Ann Arbor, 55-70.

Dover, Kenneth J. (1970), Aristophanes' Clouds, Oxford.

Finley, Moses I. (1975), “Myth, Memory and History”, in Moses I. Finley, The Use and Abuse of History, London.

Ginsburg, Judith (1981), Tradition and Theme in the Annals of Tacitus, Salem.

Gould, John (1989), Herodotus, London.

Gray, Vivienne (1987), “Mimesis in Greek Historical Theory”, American Journal of Philology 108, 467-86.

Greenwood, Emily (2006), Thucydides and the Shaping of History, London.

Grethlein, Jonas (2013), Experience and Teleology in Ancient Historiography: 'Future Past' from Herodotus to Augustine, Cambridge.

Grethlein, Jonas (2015), “Aesthetic Experiences, Ancient and Modern”, New Literary History 46, 309-33.

Harris, Edward M (2018), "Herodotus and the Social Contexts of Memory in Ancient Greece: the Individual Historian and his Community", in Zosia Archibald (ed.), The Power of the Individual in Ancient Athens: Essays in Honour of John K. Davies, London, 79-113.

Hau, Lisa (2016), Moral History from Herodotus to Diodorus Siculus, Edinburgh.

Hornblower, Simon (2013), Herodotus. Histories Book V, Cambridge.

Langslow, David (2013), “Archaic Latin Inscriptions and Greek and Latin Authors”, in Peter Liddell/Polly Low (eds.), Inscriptions and their Uses in Greek and Latin Literature, Oxford, 167-95.

Lenfant, Dominique (1999), “Peut-on se fier aux « fragments » d'historiens? L'exemple des citations d'Hérodote”, Ktèma 24, 103-21.

Lenfant, Dominique (2005), “'Polybe et les 'fragments' des historiens de Rhodes Zénon et Antisthène (XVI,14-20)”, in Guido Schepens/Jan Bollansée (eds.), The Shadow of Polybius. Intertextuality as a Research Tool in Greek Historiography. Studia Hellenistica 42, Leuven, 183-204.

Lenfant, Dominique (2013) “The Study of Intermediate Authors and its Role in the Interpretation of Historical Fragments", Ancient Society 4, 289-305.

Maier, Felix K. (2018), "Dealing with the Invisible - War in Procopius”, in Alexander Kampakoglou/Anna Novokhatko (eds.), Gaze, Vision and Visuality in Ancient Greek Literature, Berlin/Boston, 289-307.

Marincola, John (1997), Authority and Tradition in Ancient Historiography, Cambridge.

Moles, John L. (1993), "Truth and Untruth in Herodotus and Thucydides", in Christopher Gill and T.P. Wiseman (eds.), Lies and Fiction in the Ancient World, Liverpool, 88-121.

Momigliano, Arnaldo (1981), "The Rhetoric of History and the History of Rhetoric: On Hayden White's Tropes”, in Elinor S. Shaffer (ed.), Comparative Criticism. A Year Book, iii, Cambridge, 259-68.

Parmeggiani, Giovanni (1999), “Mito e spatium historicum nelle Storie di Ephoro di Cuma”, Rivista Storica dell' Antichità 29, 107-25.

Pitcher, Luke (2009), Writing Ancient History: An Introduction to Ancient Historiography, New York. 
Pownall, Frances (2004), Lessons from the Past: The Moral Use of History in Fourth-Century Prose, Ann Arbor.

Rood, Tim (1998), Thucydides. Narrative and Explanation, Oxford.

Rutherford, Richard B. (1994), “Learning from history”, in Robin Osborne/Simon Hornblower (eds.), Ritual, Finance, Politics, Oxford, 53-68.

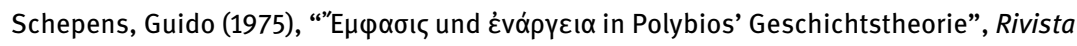
Storica dell'Antichità 5, 185-200.

Schepens, Guido (1977), "Historiographical Problems in Ephorus”, in Historiographia antiqua. Commentationes lovanienses in honorem W. Peremans septuag. Editae, Louvain, 95-118.

Thomas, Rosalind (2019), Polis Histories, Collective Memories and the Greek World, Cambridge.

Walker, Andrew D. (1993), "Enargeia and the Spectator in Greek Historiography”, Transactions of the American Philological Association 123, 353-77.

West Stephanie (1985), “Herodotus’ Epigraphical Interests”, Classical Quarterly 35, 278-305.

West, Stephanie (2012), “Skylax's problematic voyage: a note on Herodotus IV 44”, Eikasmos 23, 159-67.

West, Stephanie (2013), ““Every Picture Tells a Story”: A Note on Herodotus 4.88”, in Boris Dunsch/Kai Ruffing (eds.), Herodots Quellen-Die Quellen Herodots. Classica et Orientalia, Bd 6, Wiesbaden, 117-128.

Wheeldon, M.J. (1989), ““'True Stories”: the reception of historiography in antiquity”, in Averil Cameron (ed.), History as Text. The Writing of Ancient History, London, 36-63.

White, Hayden (1973), Metahistory: The Historical Imagination in Nineteenth-Century Europe, Baltimore, MD.

Wiseman, T.P. (1994), Historiography and Imagination. Eight Essays on Roman Culture, Exeter, $1-22$. 